\title{
Lodgepole pine and trembling aspen competition: Neighbourhood studies within 22 to 39 year-old pine plantations of northern British Columbia
}

\author{
by George Harper ${ }^{1}$
}

\begin{abstract}
Six lodgepole pine plantations located within the Sub Boreal Spruce (SBS) biogeoclimatic zone of the northern interior of British Columbia were chosen to study the impacts of neighbourhood aspen competition on the growth of planted lodgepole pine (22-39 years old). At each site, 30 pine trees (CP) were selected as plot centres across the observed range of aspen competition. Information on the six nearest neighbours (NN) and a variety of competition indices were evaluated using linear and nonlinear models. Competition indices based on diameter or height relative to size were found as the best overall predictors of CP growth. Proximity of NN to the CP was found to be inconsistent as a predictor of growth. Individual pine and aspen NN modelling suggested aspen competition had the greatest influence on CP growth restriction. The results do not support aspen thresholds for optimizing the growth of free growing pine plantations. It is recommended that performance-based standards be developed that account for aspen competition intensity and provide guidance for the management of pine stand productivity.
\end{abstract}

Key words: Lodgepole pine, aspen, boreal mixedwoods, nearest neighbours, stem volume, competition.

\section{RÉSUMÉ}

On a identifié six plantations de pin tordu situées dans la zone biogéoclimatique de lépinette sub-boréale (Sub Boreal Spruce-SBS) dans le nord de la Colombie-Britannique intérieure pour y étudier l'impact de la compétition du peuplier environnant sur la croissance de pin tordu dans des plantations de 22 à 39 ans. À chaque endroit, 30 pins (CP) ont été choisis comme centre de placette de manière à représenter tous les niveaux de compétition par le peuplier. Les renseignements pris sur les voisins les plus rapprochés $(\mathrm{NN})$ ont servi à évaluer une variété d'indices de compétition à l'aide de régressions linéaires et non linéaires. On a observé que les indices de compétition basés sur le diamètre ou la hauteur par rapport à la taille donnaient les meilleures prédictions de croissance du CP. La proximité des NN par rapport au CP a donné des prédictions de croissance qui se sont avérées incohérentes. Le modèle individuel pin et peuplier le plus rapproché laisse voir que c'est la compétition exercée par le peuplier qui limite le plus la croissance du CP. Les résultats ne permettent pas d'établir de seuils de compétition du peuplier pour optimiser la croissance des plantations de pins. Nous recommandons détablir des normes de performance qui tiennent compte de l'intensité de la compétition par le peuplier et qui puisse servir de guides pour gérer la productivité des plantations de pins.

Mots-clés: Pin tordu, peuplier, forêts mélangées boréales, plus proches voisins, volume par tige, compétition.

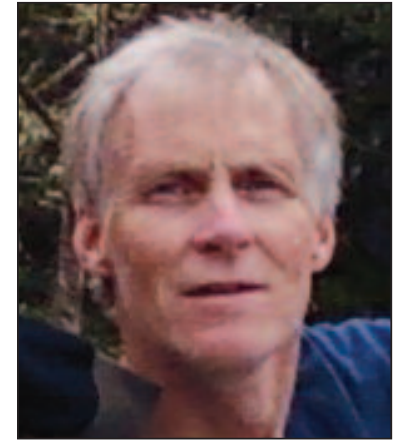

\section{Introduction}

Trembling aspen (Populus tremuloides Michx.) is frequently found mixed within managed lodgepole pine (Pinus contorta Dougl.) plantations of the Sub-Boreal Spruce biogeoclimatic zone (SBS) of British Columbia (Meidinger and Pojar 1991). Aspen usually overtops young lodgepole pine (hereafter referred to as pine) George Harper and other conifers such as white spruce (Picea glauca Moench). Overtopping aspen has been shown to influence the growing conditions of understorey trees through impacts on light, air and soil temperature, soil moisture and nutrients (McKinnon and Kayahara 2003, Voicu and Comeau 2006). When found within pine plantations, aspen is considered a major competitor, reducing survival and tree growth (Newsome et al. 2003, DeLong 2007). Aspen competition has the potential to significantly increase plantation establishment costs when manual brushing or herbicide treatments are prescribed. Several studies have suggested threshold densities for aspen, $\leq 5000$ trees per hectare (tph), where the growth of young pine may be considered unimpeded (Newsome 1999, Dhar et al. 2015). However, recent stand level studies have indicated pine productivity (stand volume and basal area) can be sensitive to even small increases in aspen composition (Harper 2015). Similar reductions in productivity with increases in broadleaf competition have been noted with loblolly pine (Pinus taeda L.; Miller et al. 2003). Studies that

${ }^{1}$ Resource Practices Branch, B.C. Ministry of Forests, Lands and Natural Resource Operations, Victoria, BC, Canada V8W 9C2; e-mail: George.Harper@gov.bc.ca 
suggest aspen threshold densities exist for unimpeded pine growth appear to contradict generally established principles of forest dynamics where tree growth is inversely related to density (Zeide 2002, Pretzsch 2009). Although total stand productivity may remain unchanged with increased levels of aspen, there is a significant decline in pine component growth and yield (Harper 2015) and several studies have documented diameter growth impacts in young pine (Newsome et al. 2008, Harper et al. 2009). Most published studies have focused on early establishment performance prior to canopy closure based on measurements of aspen competition in young pine from small plots. Some studies are without an aspen- free treatment from which to quantify a zero competition environment, which may confound attempts to define growth threshold impacts (Wagner et al. 1989). Many of the published aspen competition studies were established in response to the government's need for evidence to support regeneration standards and free-growing guidelines (Lieffers et al. 2008, Dhar et al. 2015). In British Columbia, the Forest and Range Practices Act (FRPA; BC MFLNRO 2015) requires a licence holder to establish a free-growing stand defined as a stand of healthy trees of commercial value, "the growth of which is not impeded by competition from plants, shrubs or other trees". Accepting threshold amounts of aspen at free-growing may inadvertently increase stand density, modify stand composition and impact conifer productivity. Stand regeneration research established to focus on plantation performance may not provide longterm stand-level evidence of the effects of interspecific tree competition post canopy closure.

In this paper, tree-level competition results are presented as a companion study to Harper (2015), where stand growth and yield information were presented from a retrospective study of six post-free growing SBS pine plantations. The objectives of this paper are to provide a linkage between stand growth and yield and individual tree-based measures of competition through a focus on understanding interspecific treelevel competition between aspen and pine neighbours. Explorations included measures of growing space, crown occupancy, relative size and proximity of nearest neighbours. Questions addressed were: What are the competition parameters that best describe pine growth? How important are intra or interspecific competition measures such as relative size and proximity of neighbours? And, does this evidence provide guidance on the assessment of aspen competition at freegrowing declaration and linkage to longer term pine growth and yield?

\section{Methods}

The following methods are a shorter version of those in Harper (2015). Six pine plantation sites were selected during the summers of 2013 and 2014, all located within the SBS zone of British Columbia (Table 1). The climate of the six sites is characterized by severe snowy winters and warm, moist but short summers with a mean annual temperature of $1.7^{\circ} \mathrm{C}-5$ ${ }^{\circ} \mathrm{C}$ and a mean annual precipitation of $415-1650 \mathrm{~mm}$. The sites ranged from 22-39 years since planting and were in an advanced state of early stand development, having previously been declared free-growing lodgepole pine plantations (BC MFLNRO 2013). Records indicate that clear-cut harvesting, site preparation and planting occurred at each of the six sites. Lodgepole pine seedlings were planted at all six sites. Herbicide or manual brushing treatments occurred at four of the six plantations (BE, LL, TC and CC) to control deciduous competition (primarily aspen) a minimum of 18 years prior

Table 1. Site location and silviculture history information (Harper 2015)

\begin{tabular}{|c|c|c|c|}
\hline $\begin{array}{l}\text { Site name } \\
\text { BEC variant }{ }^{\text {a }}\end{array}$ & $\begin{array}{l}\text { Lat. } \\
\text { Long. }\end{array}$ & Silviculture history & $\begin{array}{c}\text { Planted } \\
\text { pine age }\end{array}$ \\
\hline $\begin{array}{l}\text { Tamarack Lake } \\
\text { (BE) SBS dw3 }\end{array}$ & $\begin{array}{c}535230 \mathrm{~N} \\
1231912 \mathrm{~W}\end{array}$ & $\begin{array}{l}\text { Clearcut } 1983 \text { ( } 68 \mathrm{ha} \text { ), site prepared } 1984 \text { (drag scarified), herbicide } 1985 \text { (hack } \boldsymbol{n} \\
\left.\text { squirt with } \text { glyphosate }^{\mathrm{b}}\right) \text {, planted } 1986\left(2+0 \mathrm{BR}^{\mathrm{c}} \text { lodgepole pine), manual }\right. \\
\text { brushing 1993, declared Free to Grow } 1996 .\end{array}$ & 30 \\
\hline $\begin{array}{l}\text { Dog Creek (DG) } \\
\text { SBS dw3 }\end{array}$ & $\begin{array}{l}54180 \mathrm{~N} \\
12420 \mathrm{~W}\end{array}$ & $\begin{array}{l}\text { Clearcut } 1971 \text { ( } 39 \text { ha), broadcast burnt 1974, planted } 1976 \text { (PSB } 1+0 \text { lodgepole } \\
\text { pine), declared Free to Grow } 1992 .\end{array}$ & 39 \\
\hline $\begin{array}{l}\text { Loon Lake (LL) } \\
\text { SBS dk1 }\end{array}$ & $\begin{array}{c}543240 \mathrm{~N} \\
1241912 \mathrm{~W}\end{array}$ & $\begin{array}{l}\text { Clearcut } 1984 \text { (56 ha), site prepared } 1985 \text { (chain drag) \& } 1991 \text { (disked), planted } 1992 \\
\text { (2 + } 0 \text { BR lodgepole pine), manually brushed 1995, declared Free to Grow } 2000 .\end{array}$ & 24 \\
\hline $\begin{array}{l}\text { Pitka Creek (PI) } \\
\text { SBS mc2 }\end{array}$ & $\begin{array}{c}541825 \mathrm{~N} \\
1242249 \mathrm{~W}\end{array}$ & $\begin{array}{l}\text { Clearcut } 1985 \text { ( } 170 \text { ha), site prepared (disked) 1987, planted } 1988 \text { (PSB 1+0 } 313 \\
\text { lodgepole pine), declared Free to Grow } 2007 .\end{array}$ & 27 \\
\hline $\begin{array}{l}\text { Tako Creek (TC) } \\
\text { SBS dw } 2\end{array}$ & $\begin{array}{l}531840 \mathrm{~N} \\
123230 \mathrm{~W}\end{array}$ & $\begin{array}{l}\text { Clearcut } 1989 \text { ( } 69 \text { ha), site prepared } 1989 \text { (disked), planted } 1990 \text { (PSB lodgepole } \\
\text { pine), herbicide } 1996 \text { (aerial glyphosate), declared Free to Grow } 2008\end{array}$ & 24 \\
\hline $\begin{array}{l}\text { Chehishic Creek } \\
\text { (CC) SBS dw3 }\end{array}$ & $\begin{array}{c}53300 \mathrm{~N} \\
123210 \mathrm{~W}\end{array}$ & $\begin{array}{l}\text { Clearcut } 1986 \text { ( } 77 \text { ha), site prepared } 1986 \text { (chain drag) \& } 1991 \text { (disked), planted } \\
1992 \text { (PSB 1+0 313A lodgepole pine), herbicide } 1995 \text { (aerial glyphosate), declared } \\
\text { Free to Grow 2008. }\end{array}$ & 22 \\
\hline
\end{tabular}

aBiogeoclimatic ecosystem classification (BEC)

${ }^{\mathrm{b}}$ Glyphosate is the active ingredient of the herbicide Roundup or Vision used during operational treatments

${ }^{\mathrm{c}} \mathrm{BR}=$ bare root seedlings.

${ }^{\mathrm{d}} \mathrm{PSB}=$ poly-styroblock nursery containers

${ }^{\mathrm{e}}$ At plot establishment 
to this study. Glyphosate herbicide was used as part of a hackand-squirt brushing treatment at the $\mathrm{BE}$ site. A manual brushing treatment also occurred at BE (eight years after herbicide treatment) and at the LL site (three years post-planting). Aerial broadcast glyphosate application occurred at the TC and CC sites six and three years respectively after planting. Between 1000 and 1500 tph of pine were planted at the various sites. During 2013 and 2014 the six sites were assessed at least six years post free-growing declaration. Aspen occupied significant areas within these six pine plantations.

At each site, 30 pine-centered plots were established using regression sampling (Demaerschalk and Kozak 1974). Pine was selected across the observed range of aspen competition using five subjective categories of aspen presence: no aspen competition, slight, moderate, heavy and extreme, with six pines selected for each category. Pine selection included suppressed and co-dominant as well as dominant trees that had been planted. At each sample pine, a series of variable radius subplots were established following Filipescu and Comeau (2007). DBH, total height, height increments for the last two growing seasons, crown width $(\mathrm{E}, \mathrm{W}, \mathrm{N}, \mathrm{S})$, height to lowest live branch (bottom of live crown) and tree crown class (Walmsley et al. 1980) were assessed on the central pine (CP) and the nearest six neighbourhood trees (regardless of species), including their distance and azimuth.

Data analysis used SAS version 9.3 (SAS Institute Inc. 2010). Statistical significance was based on $P<0.05$. Linear and non-linear regression analysis was used to test for significant changes across a range of independent variables. Nonlinear models were used to improve predictions. Adjusted $\mathrm{R}^{2}=1-[(\mathrm{n}-1) /(\mathrm{n}-\mathrm{p})] \mathrm{SS}_{\mathrm{E}} / \mathrm{SST}_{\mathrm{C}}\left(\mathrm{R}^{2}{ }_{\text {adj }}\right)$ was calculated for all non-linear equations (Cornell and Berger 1987). Residual plots were assessed visually for each fitted equation and models were evaluated using root mean squared error (RMSE) and $\mathrm{R}^{2}$ adj. A multiple regression approach (Chen 1997) was used to determine if the data from individual sites could be pooled (i.e., besides the continuous regressor, effects were added to account for site and the site-by-regressor interaction). Non-linear models were linearized for the pooled multiple-site regression test (Proc Mixed), otherwise non-linearized results are presented (Proc NLIN). Caution was used in interpreting regression statistics since statistical significance was considered to be evidence of a response; however, the inference was not considered conclusive at the site level (Neter et al. 1990).

A variety of competition indices (CIs) were calculated to explore the influence of neighbourhood competition on pine growth (Table 2), including density by species (TPH), basal area, several measures of CI using the nearest six neighbourhood competitors (all tree species), sum of DBH distance ratio (DDR) (Canham et al. 2004), Lorimer competition index (LCI; Lorimer 1983), relative height ratio (RHT), relative crown size (RCW) and the sum of the distance (DIST). A stepwise series of nearest neighbour LCI, RHT, RCW and

Table 2. Competition indices defined. The maximum number of nearest neighbours $(n)$ considered was six.

\begin{tabular}{|c|c|c|}
\hline Competition Index & Formula & Value \\
\hline TPH (Total density) & Number / plot x per hectare multiplier & Trees / hectare (tph) \\
\hline DIST_n(Distance sum) & $\sum \mathrm{D}_{\mathrm{ij}}^{\mathrm{a}}$ & $\begin{array}{l}\text { Sum of the } n \text { nearest neighbours }\left({ }_{j}\right) \text { distance }(\mathrm{cm}) \\
\text { from centre pine }\left(_{i}\right)\end{array}$ \\
\hline RHT_ $n$ (Height ratio) $^{\mathrm{b}}$ & $\Sigma\left(\right.$ height $_{\mathrm{j}}$ / height $\left._{\mathrm{i}}\right)$ & $\begin{array}{l}\text { Relative height ratio }(\mathrm{cm} / \mathrm{cm}) \text { sum of the } n \\
\text { nearest neighbours }\end{array}$ \\
\hline $\mathrm{RHT}_{\mathrm{L}}^{\mathrm{b}}$ or $\mathrm{RHT}_{\mathrm{C}}^{\mathrm{b}}$ & Tallest or closest nearest neighbour & $\begin{array}{l}\text { Height of tallest or closest tree selected } \\
\text { respectively }(\mathrm{cm} / \mathrm{cm})\end{array}$ \\
\hline 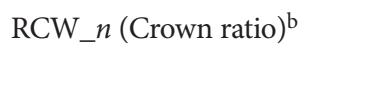 & $\Sigma\left(\right.$ crown $^{\text {radius }}$ / crown radius $\left._{\mathrm{i}}\right)$ & $\begin{array}{l}\text { Relative crown ratio }(\mathrm{cm} / \mathrm{cm}) \text { sum of the } n \\
\text { nearest neighbours }\end{array}$ \\
\hline $\mathrm{RCW}_{\mathrm{L}}^{\mathrm{b}}$ or $\mathrm{RCW}_{\mathrm{C}}^{\mathrm{b}}$ & Largest or closest nearest neighbour & $\begin{array}{l}\text { Crown ratio of largest or closest tree selected } \\
\text { respectively }(\mathrm{cm} / \mathrm{cm})\end{array}$ \\
\hline 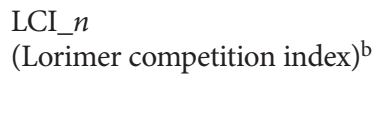 & $\Sigma\left(\mathrm{DBH}_{\mathrm{j}} / \mathrm{DBH}_{\mathrm{i}}^{\mathrm{c}}\right)$ & $\begin{array}{l}\text { Relative DBH ratio }(\mathrm{cm} / \mathrm{cm}) \text { sum of the } n \text { nearest } \\
\text { neighbours }\end{array}$ \\
\hline $\begin{array}{l}\mathrm{LCI}_{\mathrm{L}} \text { or } \mathrm{LCI}_{C} \\
\text { (Modified LCI) }^{\mathrm{b}}\end{array}$ & Largest or closest tree & $\begin{array}{l}\mathrm{DBH}_{\mathrm{j}} / \mathrm{DBH}_{\mathrm{i}} \mathrm{DBH} \text { ratio of largest or closest tree } \\
\text { respectively }(\mathrm{cm} / \mathrm{cm})\end{array}$ \\
\hline DRD_n & $\Sigma\left[\left(\mathrm{DBH}_{\mathrm{j}} / \mathrm{DBH}_{\mathrm{i}}\right) / \mathrm{D}_{\mathrm{ij}}\right]$ & $\begin{array}{l}\text { Diameter ratio divided by distance }(\mathrm{cm} / \mathrm{cm} / \mathrm{cm}) \\
\text { of the } n \text { nearest neighbours }\end{array}$ \\
\hline
\end{tabular}

${ }^{\mathrm{a}} \mathrm{D}_{\mathrm{ij}}=$ distance between the centre pine and the nearest neighbour $(\mathrm{cm})$

${ }^{b}$ Based on the six nearest neighbour trees to the centre pine, where $n=$ sum of closest $(\mathrm{C})$ to farthest (6) nearest neighbours

${ }^{\mathrm{c}} \mathrm{DBH}_{\mathrm{i}}=$ diameter breast height of centre pine $(\mathrm{cm})$ 
Table 3. Equation coefficients for the linear model describing each site centre pine DBH and height over total density (tph), where the dependent variables DBH and height $=a+b$ (tph)

\begin{tabular}{|c|c|c|c|c|c|c|c|c|c|}
\hline & \multicolumn{6}{|l|}{ Main model } & \multicolumn{3}{|c|}{ Multiple-site model } \\
\hline & Site $^{\mathrm{a}}$ & $\mathbf{a}$ & $\mathbf{b}$ & $\mathbf{R}_{\text {adj }}^{2}$ & RMSE $^{\mathbf{b}}$ & $P$ value & $\begin{array}{c}\text { Source of } \\
\text { variation }\end{array}$ & $\mathbf{F}$ & $P$ value \\
\hline \multirow[t]{6}{*}{$\mathrm{DBH}$} & Tamarack Lake (BE) & 15.3 & -0.00017 & 0.028 & 2.77 & 0.185 & PC & - & $<0.0001$ \\
\hline & Dog Creek (DG) & 17.8 & -0.0006 & 0.30 & 3.08 & 0.001 & Site & - & 0.03 \\
\hline & Loon Lake (LL) & 15.3 & -0.0004 & 0.22 & 2.68 & 0.0052 & PC $x$ Site & - & 0.004 \\
\hline & Pitka Creek (PI) & 18.5 & -0.001 & 0.47 & 3.29 & $<0.0001$ & - & - & - \\
\hline & Tako Creek (TC) & 17.8 & -0.0013 & 0.17 & 3.32 & 0.013 & - & - & - \\
\hline & Chehishic Creek (CC) & 12.5 & -0.00003 & -0.036 & 3.57 & 0.949 & - & - & - \\
\hline \multirow[t]{6}{*}{ Height } & Tamarack Lake & 1305.2 & -0.009 & 0.03 & 152.06 & 0.18 & $\mathrm{PC}$ & - & $<0.0001$ \\
\hline & Dog Creek & 1729.4 & -0.03 & 0.22 & 210.07 & 0.005 & Site & - & $<0.0001$ \\
\hline & Loon Lake & 1154.0 & -0.019 & 0.10 & 169.01 & 0.048 & PC $x$ Site & - & 0.016 \\
\hline & Pitka Creek & 1464.2 & -0.056 & 0.35 & 234.5 & 0.0003 & - & - & - \\
\hline & Tako Creek & 1407.1 & -0.067 & 0.11 & 212.79 & 0.044 & - & - & - \\
\hline & Chehishic Creek & 1048.6 & 0.007 & -0.033 & 229.99 & 0.782 & - & - & - \\
\hline
\end{tabular}

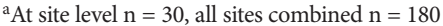

${ }^{b}$ Root mean squared error

DIST, including the largest or tallest competitor (LCI_L, DIST_L, RCW_L or RHT_L) and the closest competitor (LCI_C, DIST_C, RCW_C or RHT_C) were evaluated. The relative size of the competitor to the sample pine based on $\mathrm{DBH}$ and weighted by distance was also assessed (DRD; Daniels 1976). Dependent variables of CP growth included absolute measures of $\mathrm{DBH}$, height, leader growth, crown radius and stem volume. Relative measures of $\mathrm{CP}$ growth were calculated to facilitate comparisons between sites (relative to the largest $\mathrm{CP}$ per site).

\section{Results}

At each of the six sites a wide range of aspen-pine mixedwood stand conditions were sampled. Aspen density ranged from 0 to 15500 trees/hectare (tph) and pine density from 100 to $8900 \mathrm{tph}$. Stand canopies were dominated by pine, aspen or a mix of the two with a total density from 1350 to 18100 tph (Harper 2015). Centre pine DBH and height declined with density at four of the six sites (BE and CC were the exceptions) with linear models used to describe the site-dependent tree size decline (Table 3). Fig. 1 shows a scatterplot of height versus $\mathrm{DBH}$ for the six nearest neighbours $(\mathrm{NN})$ at each site by species. The average nearest neighbour distance, absolute and relative size statistics at each site separated by species are provided in Table 4 . The average distance to the closest neighbour ranged from 98 to $161 \mathrm{~cm}$ across the sites but, on a tree by tree basis, could be as little as 5 to as far as $301 \mathrm{~cm}$ (data not shown). Average NN distance to the $\mathrm{CP}$ and average $\mathrm{NN}$ DBH were consistently greater for the pine NN. Average height difference between pine and aspen NN were sitedependent with DG, LL, and CC sites suggesting similar average heights. Relative measures of neighbour size (ratios of neighbour size to $\mathrm{CP}$ size for $\mathrm{DBH}$, height and crown radius) were calculated (see Table 2 and Table 4 ) to facilitate site comparisons. Average NN relative diameter (LCI) and crown radius (RCW) were greater for the aspen $\mathrm{NN}$ at four of the six sites (BE and LL exceptions). The average relative height
(RHT) of aspen NN was 10 to $50 \%$ greater than pine $\mathrm{NN}$ at five of the six sites (BE the exception). The average pine NN RHT was consistently close to 1.0 across all six sites.

Fig. 2 presents a scatterplot of the closest neighbour relative diameter (LCI_C) and relative height (RHT_C) vs. the distance (DIST_C) by site and species. No apparent or significant linear relationships between the NN LCI_C, RHT_C and DIST_C were found. Similar non-significant results using all six nearest neighbours' data were also noted (results not shown).

The range of species composition of the six NN is presented in Fig. 3 where the average NN relative height (RHT_A) for each CP by site is plotted over the count of the number of $\mathrm{NN}$ which were conifer $(0=$ no pine neighbours, all six neighbours counted as broadleaf, primarily aspen), $1=$ one pine and five aspen, 2 = two pine and four aspen, etc.). The green shaded area of Fig. 3 indicates an increase in the maximum RHT_A distribution as NN pine composition declined (aspen $\mathrm{NN}$ composition increased). The majority of RHT_A distribution occurs within the 1.2 to 0.8 range (light blue shaded area). RHT_A from 1.2 to 3.2 was found only where the NN conifer count $<3$ represented NN aspen composition from 50 to $100 \%$. Diagrams provided illustrate general neighbourhood canopy types associated with the distribution of RHT_A and NN species composition.

Various CI's (Table 2) were evaluated using linear models to describe $\mathrm{CP}$ growth (DBH, height, crown radius, leader growth, stem volume (STV) and relative stem volume (R_STV, relative to maximum CP STV observed per site). Individual CI's incrementally included $\mathrm{NN}$ sorted by distance using a stepwise approach of assessing $\mathrm{CP}$ growth parameters by summing the CI of neighbours found further and further away. Table 5 presents the $\mathrm{R}_{\text {adj }}^{2}$ for significant models $(\mathrm{P}<$ 0.05 ) for $\mathrm{CP}$ growth parameters regressed against $\mathrm{NN}$ relative size (LCI variables) for each site (not all growth parameters shown). The maximum predictive ability $\left(\mathrm{R}^{2}{ }_{\text {adj }}\right)$ at each site for CP DBH was found using the CI LCI_L (using the largest 

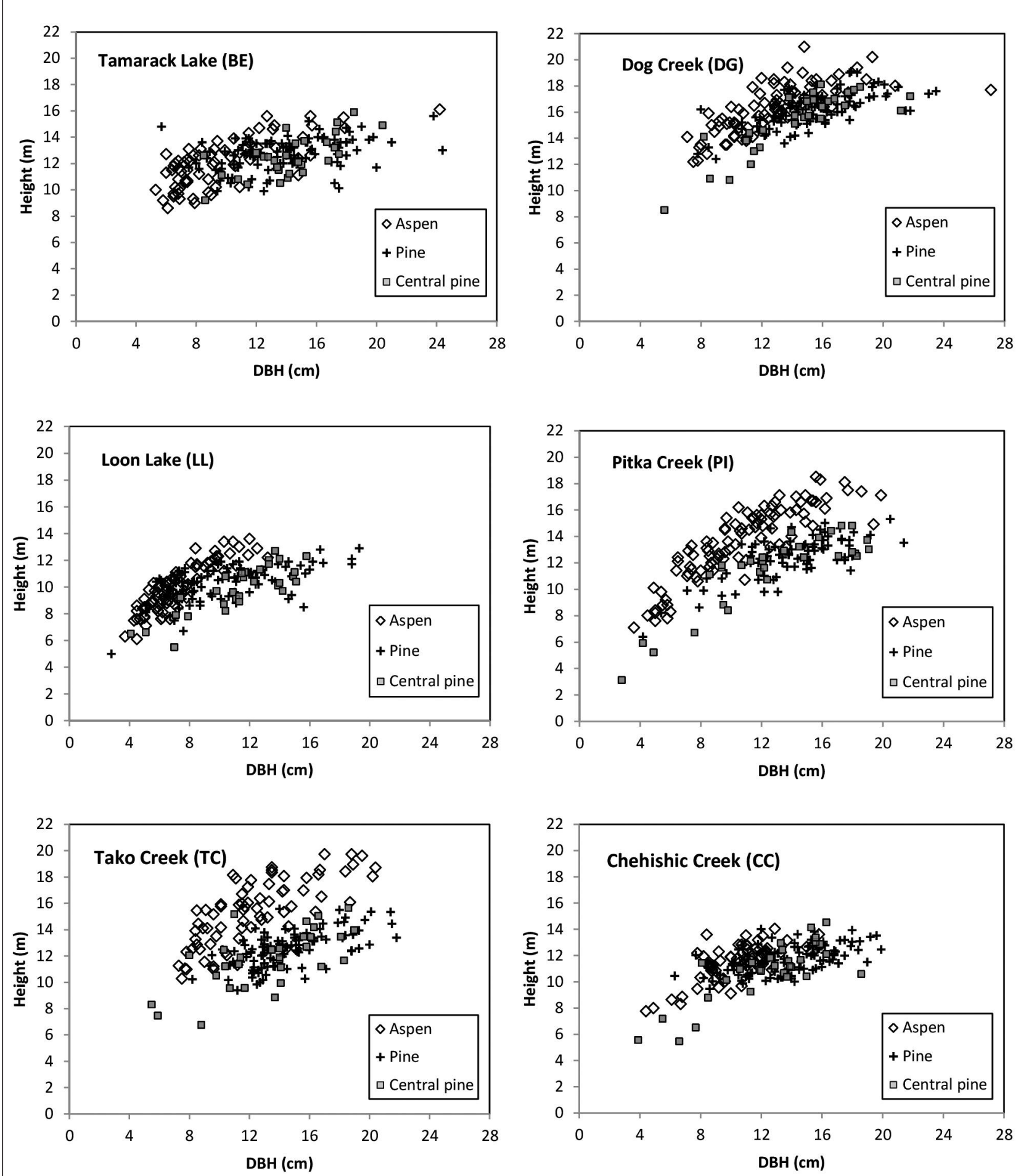

Fig. 1. Nearest six neighbours and centre pine tree heights over DBH by site.

DBH NN) or LCI_6 (sum of all six NN). At site BE, CP DBH was found to have no significant correlation with the nearest three neighbour tree LCI variables (LCI_C - LCI_3). Similar $\mathrm{BE}$ results were noted when LCI variables were used to predict CP height, STV and R_STV. Poor linear model results were noted with CP average leader growth (A_LDR) at BE and DG sites. Multiple site results (Proc Mixed) suggested pooling of data from all sites was appropriate for $\mathrm{CP} \mathrm{DBH}$, A_LDR and R_STV only since the site $\mathrm{x}$ regressor and site terms were non-significant $(\mathrm{P}>0.05$; results not shown). 
Table 4. Mean and standard deviation for the six nearest neighbours absolute and relative size and distance, by site and species (all species $n=180$ )

\begin{tabular}{|c|c|c|c|c|c|c|c|c|}
\hline Site & $\begin{array}{c}\text { NN } \\
\text { Species }\end{array}$ & $\begin{array}{l}\text { Distance } \\
(\mathrm{cm})^{\mathrm{a}}\end{array}$ & $\begin{array}{l}\text { Height } \\
\text { (m) }\end{array}$ & $\begin{array}{l}\mathrm{DBH} \\
(\mathrm{cm})\end{array}$ & $\begin{array}{c}\text { Crown } \\
\operatorname{radius~}(\mathrm{cm})\end{array}$ & $\begin{array}{c}\text { DBH ratio } \\
\left(_{(\mathrm{LCI})^{\mathrm{b}}}\right.\end{array}$ & $\begin{array}{l}\text { Height ratio } \\
{\text { (RHT })^{\mathbf{b}}}\end{array}$ & $\begin{array}{c}\text { Crown } \\
\text { radius } \\
\text { ratio }(\mathrm{RCW})^{\mathrm{b}}\end{array}$ \\
\hline Tamarack Lake (BE) & $\begin{array}{l}\text { aspen } \\
\text { pine }\end{array}$ & $\begin{array}{c}221 \pm 99.7^{c} \\
271.3 \pm 113.1\end{array}$ & $\begin{array}{l}11.9 \pm 1.9 \\
12.7 \pm 1.2\end{array}$ & $\begin{array}{c}9.6 \pm 3.6 \\
13.9 \pm 3.4\end{array}$ & $\begin{array}{l}114.1 \pm 41.5 \\
133.8 \pm 51.1\end{array}$ & $\begin{array}{c}0.75 \pm 0.3 \\
0.95 \pm 0.26\end{array}$ & $\begin{array}{c}1.0 \pm 0.19 \\
0.99 \pm 0.11\end{array}$ & $\begin{array}{l}0.85 \pm 0.34 \\
0.87 \pm 0.34\end{array}$ \\
\hline Dog Creek (DG) & $\begin{array}{l}\text { aspen } \\
\text { pine }\end{array}$ & $\begin{array}{c}201.9 \pm 85.8 \\
262 \pm 70.9\end{array}$ & $\begin{array}{l}16.3 \pm 1.9 \\
16.2 \pm 1.3\end{array}$ & $\begin{array}{l}12.7 \pm 3.4 \\
15.4 \pm 2.9\end{array}$ & $\begin{array}{l}126.2 \pm 40.4 \\
120.1 \pm 31.4\end{array}$ & $\begin{array}{c}1.13 \pm 0.51 \\
1.0 \pm 0.24\end{array}$ & $\begin{array}{c}1.2 \pm 0.34 \\
1.02 \pm 0.14\end{array}$ & $\begin{array}{c}1.4 \pm 0.58 \\
1.11 \pm 0.39\end{array}$ \\
\hline Loon Lake (LL) & $\begin{array}{l}\text { aspen } \\
\text { pine }\end{array}$ & $\begin{array}{l}171.5 \pm 77.1 \\
192.6 \pm 94.0\end{array}$ & $\begin{array}{c}9.9 \pm 1.8 \\
10.3 \pm 1.3\end{array}$ & $\begin{array}{c}7.2 \pm 2.1 \\
10.4 \pm 3.4\end{array}$ & $\begin{array}{c}90.1 \pm 29.2 \\
107 \pm 42.3\end{array}$ & $\begin{array}{l}0.79 \pm 0.35 \\
0.85 \pm 0.31\end{array}$ & $\begin{array}{c}1.13 \pm 0.25 \\
0.98 \pm 0.1\end{array}$ & $\begin{array}{c}0.83 \pm 0.34 \\
0.8 \pm 0.38\end{array}$ \\
\hline Pitka Creek (PI) & $\begin{array}{l}\text { aspen } \\
\text { pine }\end{array}$ & $\begin{array}{l}201.8 \pm 88.1 \\
258.7 \pm 75.5\end{array}$ & $\begin{array}{l}13.6 \pm 2.7 \\
12.4 \pm 1.6\end{array}$ & $\begin{array}{l}10.8 \pm 3.7 \\
13.9 \pm 3.2\end{array}$ & $\begin{array}{l}114.4 \pm 34.7 \\
139.6 \pm 44.2\end{array}$ & $\begin{array}{c}1.2 \pm 0.7 \\
0.92 \pm 0.2\end{array}$ & $\begin{array}{c}1.5 \pm 0.7 \\
0.98 \pm 0.13\end{array}$ & $\begin{array}{c}1.1 \pm 0.48 \\
0.94 \pm 0.37\end{array}$ \\
\hline Tako Creek (TC) & $\begin{array}{l}\text { aspen } \\
\text { pine }\end{array}$ & $\begin{array}{c}237.6 \pm 106.2 \\
294.3 \pm 92\end{array}$ & $\begin{array}{l}15.3 \pm 2.5 \\
12.5 \pm 1.3\end{array}$ & $\begin{array}{l}12.4 \pm 3.4 \\
14.5 \pm 2.8\end{array}$ & $\begin{array}{l}174.4 \pm 47.2 \\
157.3 \pm 39.2\end{array}$ & $\begin{array}{c}1.23 \pm 0.59 \\
1.04 \pm 0.3\end{array}$ & $\begin{array}{l}1.48 \pm 0.45 \\
1.03 \pm 0.19\end{array}$ & $\begin{array}{l}1.37 \pm 0.55 \\
0.97 \pm 0.32\end{array}$ \\
\hline Chehishic Creek (CC) & $\begin{array}{l}\text { aspen } \\
\text { pine }\end{array}$ & $\begin{array}{c}230.1 \pm 93.2 \\
277.3 \pm 102.4\end{array}$ & $\begin{array}{c}11.5 \pm 1.5 \\
11.7 \pm 1\end{array}$ & $\begin{array}{l}10.2 \pm 2.2 \\
13.5 \pm 2.8\end{array}$ & $\begin{array}{l}138.3 \pm 38.4 \\
161.5 \pm 43.1\end{array}$ & $\begin{array}{l}1.22 \pm 0.66 \\
1.03 \pm 0.28\end{array}$ & $\begin{array}{c}1.3 \pm 0.52 \\
1.04 \pm 0.15\end{array}$ & $\begin{array}{c}1.2 \pm 0.48 \\
1.06 \pm 0.38\end{array}$ \\
\hline
\end{tabular}

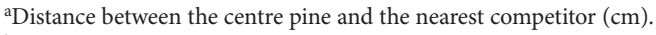

${ }^{b}$ Ratio of nearest neighbour DBH $(\mathrm{cm})$, height $(\mathrm{cm})$ or crown radius $(\mathrm{cm}) /$ centre pine DBH, height or crown radius (LCI_C, RHT_C or RCW_C respectively).

${ }^{\mathrm{c}}$ Mean and standard deviation.

Linear regression results of CP growth parameters using relative height (RHT) variables were similar to that of LCI variables (results not shown).

Distance to the six NN from the CP (DIST) was also explored in a similar fashion as the LCI and RHT variables using the stepwise approach by adding DIST of neighbours found further and further away (Table 6). Significant linear models described the CP DBH increase with increased NN DIST at five of the six sites (BE the exception), however the relationship at the LL site was poor $\left(\mathrm{R}^{2}\right.$ adj $\left.\leq 0.11\right)$. CP height, STV and R_STV increased with NN DIST at four of the six sites (DG, PI, TC and CC) but poor results were noted at the CC site. The NN DIST variables were significant for describing A_LDR only at site TC. Mixed model results suggested pooling of data from all sites was not valid for any CP growth parameters (results not shown) using NN DIST variables.

Fig. 4 presents the change in $\mathrm{R}^{2}$ adj results of the various $\mathrm{NN}$ RHT, LCI (Table 5) and DIST (Table 6) CI variables from closest to farthest cumulative NN distance. Selection of an optimum CI based on predictive ability $\left(\mathrm{R}^{2}\right.$ adj $)$ was not apparent for DIST and LCI across the sites. Maximum $\mathrm{R}^{2}$ adj appear the most consistent across sites using RHT containing NNs $4^{\text {th }}-6^{\text {th }}$ (Fig. $4 a, \mathrm{RHT}_{-} 4$ to RHT_6).

In an attempt to quantify the influences of aspen and pine $\mathrm{NN}$ on $\mathrm{CP}$ growth, additional linear regression predictions of R_STV were performed using the independent variables LCI, DIST and RHT broken down into separate conifer (pine) and broadleaf (aspen) components. For brevity, the results from the linear regressions are not presented. However, nonlinear modelling results using LCI_6 are presented in Table 7. The exponential model, R_STV $=a e^{b \text { LCI_6 }}(1)$ was selected to improve linear model fit parameters and provide site and species equation coefficients. Similar nonlinear results for RHT and DIST were also reviewed but for brevity are not presented. The CI, sum of all six NN relative sizes (LCI_6) was selected for several reasons. Both RHT and LCI CI variables generally appeared consistent in terms of the pooled sites linear and nonlinear fit results however, LCI is based on DBH measures which are much easier to acquire in closed canopies where height measurements may be less accurate. Also, DBH growth measures are more sensitive to competition than height (Zeide 2002). LCI_L was also considered a comparable alternate. Nonlinear model results using separated aspen and pine NN components (Table 7) indicated differences in predictive ability between species. Aspen $\mathrm{R}^{2}$ adj by site $(0.13$ to $0.57)$ was greater than that of pine across all sites. Pine $R^{2}$ adj results were in general very poor $(-0.04$ to 0.28$)$ with model results for site TC non-significant $(\mathrm{P}=0.999)$. Except for site $\mathrm{BE}$, all equation $1 \mathrm{Y}$-intercept coefficients (a) were larger for the aspen component than the pine component analysis. The results from Proc Mixed suggested sites could not be pooled when NN data was separated into aspen and pine components. Fig. 5 (a-c, by species) presents the entire NN dataset (n $=1080$ trees) plotting CP R_STV over NN LCI, RHT and DIST competition variables. This series of graphs provides a visual comparison across the aspen and pine NN components and a visual reference to the linear and nonlinear model results. The scatterplots of LCI and RHT (Fig. 5a \& b) clearly show an exponential decline in CP relative size (R_STV) with increasing NN competition levels across both aspen and pine components. The maximum range of the aspen component $\mathrm{CI}$ data for both RHT and LCI was larger than the pine component $\mathrm{CI}$, indicating extreme competition neighbours were found associated with aspen and not pine. The wide data dis- 

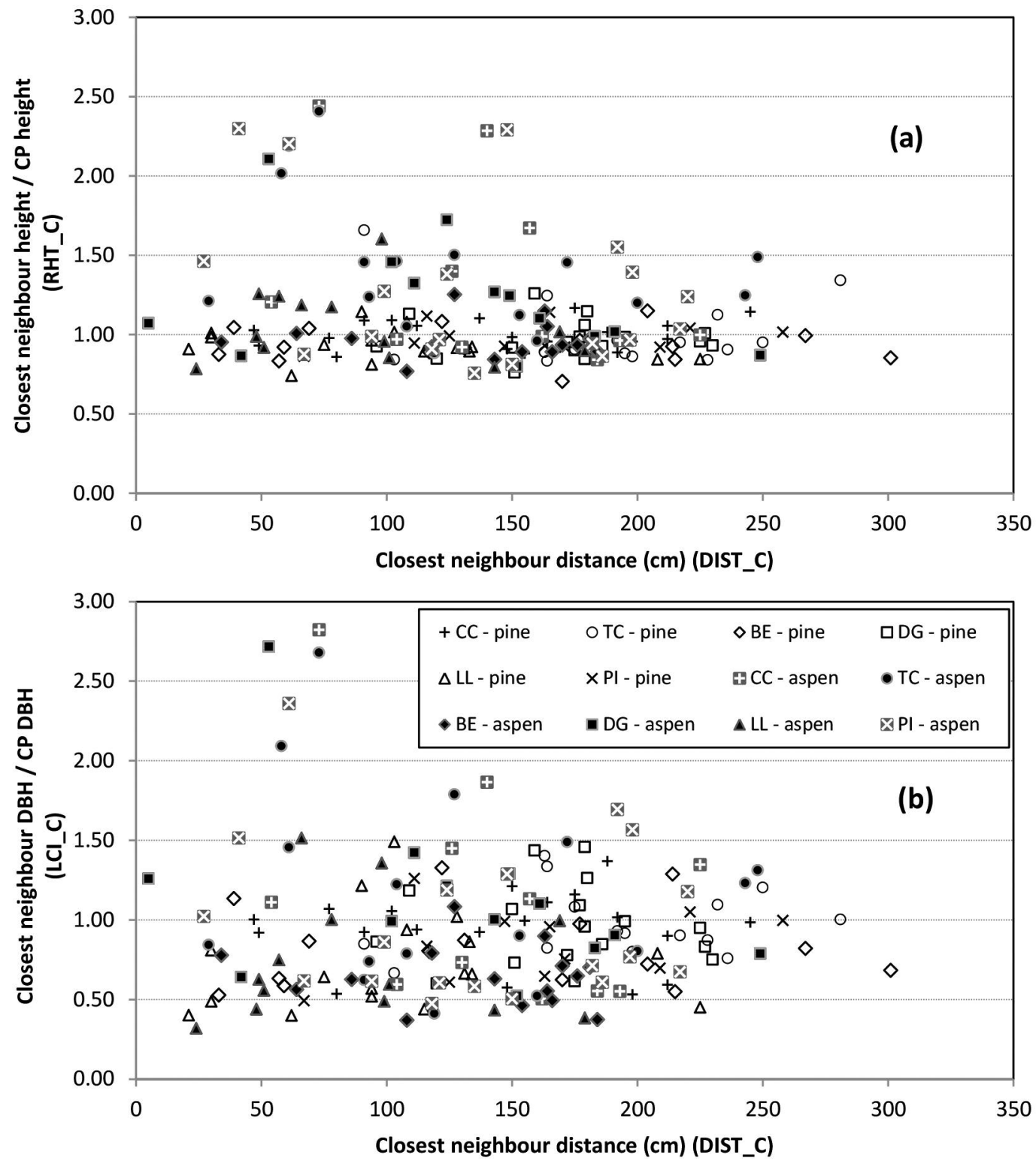

Fig. 2. Closest neighbour relative growth over distance from centre pine (CP) where relative growth is defined as neighbour height over $\mathrm{CP}$ height (a) or neighbour DBH over $\mathrm{CP} \mathrm{DBH}$ (b), by site and species (pine or aspen) ( $\mathrm{P} \geq 0.137$ and 0.125 respectively by site and species].

tribution of NN distance (DIST; Fig. 5c) provided visual evidence of the poor correlation with CP R_STV. A linear increase in CP R_STV with increasing NN distance (DIST) was apparent with only the aspen component. The pine component DIST showed no significant relationship to CP R_STV.

\section{Discussion}

Nearest neighbour assessments were used to explore the aspen - pine tree level competition providing linkage to the previously published stand level forest productivity results (Harper 2015). Impacts to pine stand volume and basal area due to increases in aspen composition and density were noted at all six sites (Harper 2015). Historically, aspen brushing treatments have been used to ensure the survival and growth of planted conifers (Comeau et al. 1999). In this paper, CP $\mathrm{DBH}$ and height (on four of the six sites) were shown to decline with increases in total density (Table 3 ) and through inference with Fig. 1 of Harper (2015), increases in aspen density and composition. DeLong (2007) also noted declining pine height and diameter growth with increases in aspen density. These observations were not unexpected since pine is known to be sensitive to stand density (Johnstone and Pollack 1990, Johnstone and van Thienen 2011).

Pine yield sensitivity (the ratio of model slope coefficients 


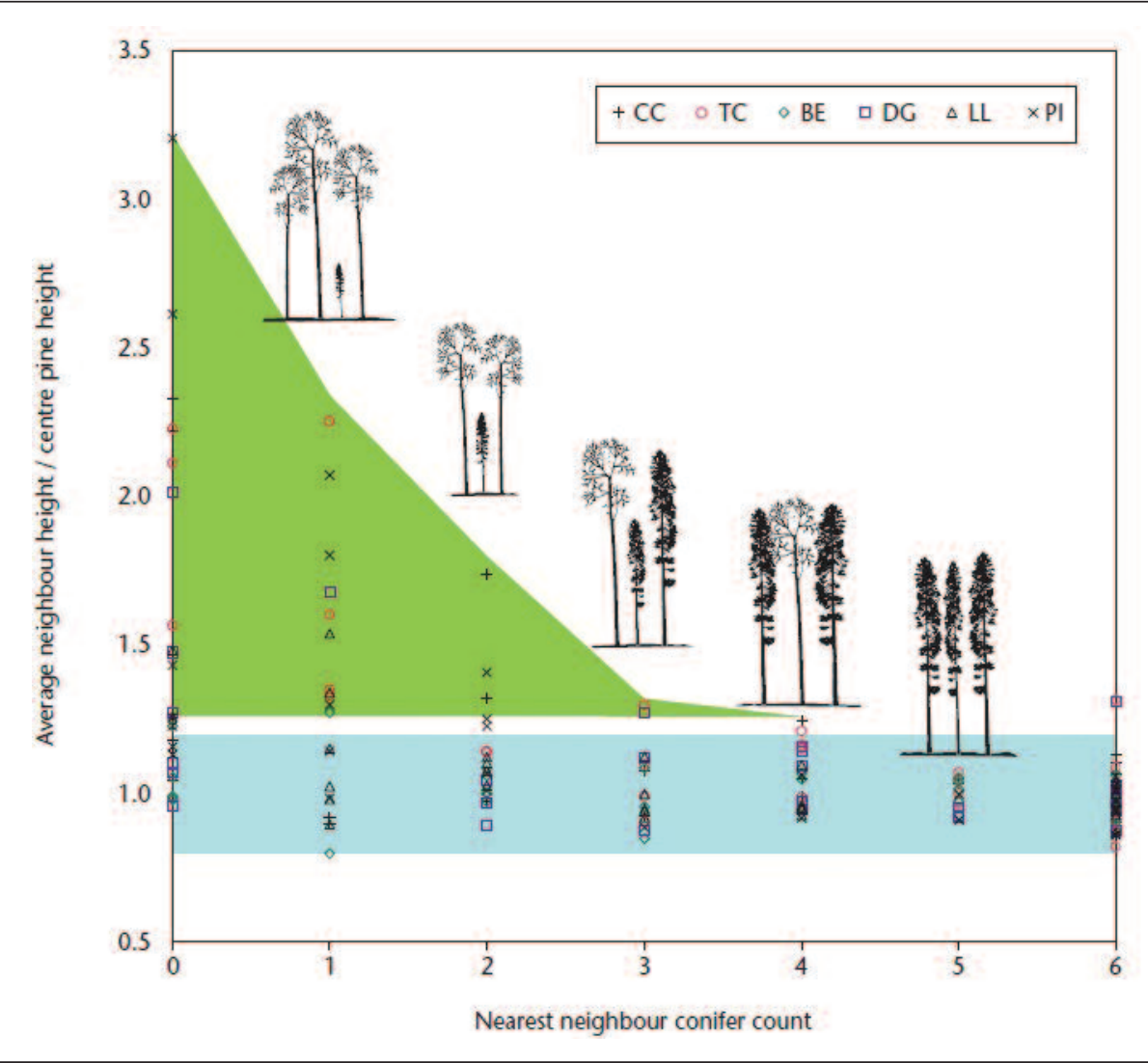

Fig. 3. Central pine average relative nearest neighbour height (RHT) plotted over total count of six nearest neighbours (NN) that were conifer (primarily pine) by site. For example, a zero count indicates all six NN were broadleaf trees (primarily aspen), a six count indicates all NN were 100\% conifer and, a three count; 50/50 mix of broadleaf / conifer. Light blue-shaded area represents the $20 \%$ relative height range above or below height equality $(\mathrm{RHT}=1.0)$.

bours. Aspen regeneration is frequently found highly clumped (Frey et al. 2003), and therefore high variability in neighbourhood inter and intraspecific competition is to be expected within mixed pine-aspen stands and the six sites studied here. The regular spacing of planted pine within and between regenerating aspen clumps and possible natural pine ingress is a recipe for high spatial variability in tree-level competition, density and canopy crowding. Exploring the nearest neighbour data from the six sites provided the opportunity to quantify this complexity, as well as provided a simplified understanding of the observed aspen-pine mixtures, $\mathrm{CP}$ neighbourhood competition and tree level productivity.

\section{Nearest neighbour (NN) site and species statistics}

The significance of the NN by species becomes apparent when viewing the height over $\mathrm{DBH}$ plots of Fig. 1 and the site statistics of distance and size in Table 4. The site-level means show average aspen $\mathrm{NN}$ were found closer to the CP than the pine $\mathrm{NN}$. Also, average pine NN were larger in DBH than aspen NN.

for aspen and pine, see Harper 2015) to changes in aspen composition was found to vary by site with the highest volume reduction noted at sites BE and CC. South and Miller (2007) presented a similar pine volume sensitivity ratio to describe loblolly pine plantation response to hardwood competition reduction (considered a Type 2 growth response). Wagner et al. (2006) noted controlling broadleaf tree competition effectively produces a response similar to a Type 2 although site productivity remains unchanged. The pine growth response noted here is consistent with those observations from loblolly pine where hardwood competition may not allow pines to dominate or "outgrow" the hardwoods without removal treatments and where the pine volume proportion in mixed stands is dependent upon the amount of hardwood dominance and canopy displacement (Miller et al. 1991).

A discussion of nearest neighbourhoods and the relationship of individual pine growth to neighbourhood density or tree crowding depends upon many factors, key of which are local site productivity, species composition and the availability of exploitable canopy space (Zeide 1989, Lhotka and Loewenstein 2008, Pretzsch and Biber 2016). It has been noted that density measures do not accurately account for the spatial variation between trees nor canopy occupancy or gaps. Zeide (2002) suggested density, defined as trees per unit area, does not accurately reflect the influences of patchy spatial distributions, the degree of crowding or proximity of neigh-
These observations are consistent with the regeneration differences between the species and the brushing treatment history. The closer distance of the aspen $\mathrm{NN}$ is likely due to aspen root sucker regeneration in dense clumps (Frey et al. 2003).

Nearest neighbour relative size statistics (LCI, RHT and $\mathrm{RCW}$ ) were on average greater for aspen than pine at four (LCI and RCW) to five (RHT) of the six sites (BE and LL the exceptions). However, these average relative size observations by site and species appear to contradict average absolute measures, in particular where average pine NN DBH was found consistently greater than the average aspen NN DBH, yet average aspen NN LCI was larger at four of the six sites. This apparent contradiction highlights the importance of spatially linked, tree-level analysis of neighbourhood competition and the variability that is not readily apparent when viewing simple site level statistics. For example the visual comparison of pooled aspen and pine height - DBH relationships in Fig. 1 showed, at the site level, many aspen NN were taller than many of the $\mathrm{CP}$ and $\mathrm{NN}$ pine for a similar $\mathrm{DBH}$ (e.g., sites PI, TC and DG). In reality, a range of mixedwood canopy patterns were found within each site which varied from aspen or pine dominance to aspen-pine coexistence as indicated in Fig. 3.

It is important to remember that these mixed canopy states are the result of incremental stand dynamics dependent on site silvicultural history and environmental conditions (Pret- 
Table 5. The predictive ability $\left(\mathrm{R}^{2}{ }_{\text {adj }}\right.$ ) of centre pine growth variables (CPG: DBH and height, average leader growth for last two years (A_LDR), stem volume [STV] and relative stem volume (R_STV: CP stem volume/maximum CP stem volume/site) fitting the linear model CPG $=a+b$ LCl where the Lorimer competition index (LCl) was calculated from nearest neighbours data by site ( $\mathrm{LCl}$ : stepwise addition of nearest neighbours closest through farthest distance and largest) (Largest $\mathrm{R}^{2}{ }_{\text {adj }}$ bolded). Values presented for significant models only $(P<0.05)$.

\begin{tabular}{|c|c|c|c|c|c|c|c|c|}
\hline Site & CPG & LCI_C ${ }^{a}$ & LCI $2^{b}$ & LCI_3 ${ }^{b}$ & LCI_4 ${ }^{b}$ & LCI_5 ${ }^{b}$ & LCI_6 ${ }^{b}$ & LCI_L ${ }^{a}$ \\
\hline \multirow[t]{4}{*}{ Tamarack Lake (BE) } & $\mathrm{DBH}$ & - & - & - & 0.16 & 0.19 & 0.28 & 0.20 \\
\hline & HT & - & - & - & 0.10 & 0.12 & 0.13 & 0.21 \\
\hline & A_LDR & - & - & - & - & - & - & - \\
\hline & R_STV, STV & - & - & 0.13 & 0.24 & 0.24 & 0.28 & 0.27 \\
\hline \multirow[t]{4}{*}{ Dog Creek (DG) } & $\mathrm{DBH}$ & 0.47 & 0.55 & 0.54 & 0.57 & 0.58 & 0.59 & 0.49 \\
\hline & $\mathrm{HT}$ & 0.46 & 0.48 & 0.48 & 0.50 & 0.54 & 0.58 & 0.43 \\
\hline & A_LDR & - & - & - & - & - & - & - \\
\hline & R_STV,STV & 0.37 & 0.44 & 0.43 & 0.46 & 0.47 & 0.47 & 0.39 \\
\hline \multirow[t]{4}{*}{ Loon Lake (LL) } & $\mathrm{DBH}$ & 0.40 & 0.33 & 0.39 & 0.42 & 0.38 & 0.43 & 0.33 \\
\hline & HT & 0.12 & - & 0.14 & 0.16 & 0.14 & 0.17 & 0.15 \\
\hline & A_LDR & 0.12 & 0.11 & 0.15 & 0.17 & 0.15 & 0.19 & 0.22 \\
\hline & R_STV, STV & 0.28 & 0.20 & 0.30 & 0.30 & 0.25 & 0.30 & 0.26 \\
\hline \multirow[t]{4}{*}{ Pitka Creek (PI) } & $\mathrm{DBH}$ & 0.19 & 0.43 & 0.48 & 0.52 & 0.57 & 0.61 & 0.58 \\
\hline & HT & 0.21 & 0.48 & 0.57 & 0.59 & 0.61 & 0.69 & 0.71 \\
\hline & A_LDR & - & 0.18 & 0.24 & 0.26 & 0.24 & 0.30 & 0.33 \\
\hline & R_STV, STV & 0.14 & 0.32 & 0.34 & 0.35 & 0.39 & 0.41 & 0.37 \\
\hline \multirow[t]{4}{*}{ Tako Creek (TC) } & $\mathrm{DBH}$ & 0.56 & 0.67 & 0.69 & 0.68 & 0.69 & 0.71 & 0.74 \\
\hline & $\mathrm{HT}$ & - & 0.16 & 0.15 & 0.16 & 0.16 & 0.16 & 0.26 \\
\hline & A_LDR & 0.20 & 0.20 & 0.19 & 0.21 & 0.19 & 0.17 & 0.20 \\
\hline & R_STV, STV & 0.32 & 0.41 & 0.43 & 0.42 & 0.44 & 0.46 & 0.54 \\
\hline \multirow[t]{4}{*}{ Chehishic Creek (CC) } & $\mathrm{DBH}$ & 0.57 & 0.64 & 0.58 & 0.59 & 0.61 & 0.64 & 0.73 \\
\hline & HT & 0.41 & 0.47 & 0.43 & 0.45 & 0.48 & 0.51 & 0.59 \\
\hline & A_LDR & 0.34 & 0.42 & 0.39 & 0.40 & 0.44 & 0.45 & 0.47 \\
\hline & R_STV, STV & 0.44 & 0.49 & 0.42 & 0.45 & 0.47 & 0.49 & 0.58 \\
\hline \multirow[t]{5}{*}{ All sites } & $\mathrm{DBH}$ & 0.29 & 0.34 & 0.37 & 0.40 & 0.41 & 0.45 & 0.47 \\
\hline & $\mathrm{HT}$ & - & - & - & - & - & - & - \\
\hline & A_LDR & 0.16 & 0.18 & 0.18 & 0.20 & 0.19 & 0.21 & 0.21 \\
\hline & STV & - & - & - & - & - & - & - \\
\hline & R_STV & 0.25 & 0.30 & 0.32 & 0.34 & 0.35 & 0.38 & 0.37 \\
\hline
\end{tabular}

aLCI_C, LCI_L using closest or largest tree $\mathrm{DBH}_{\mathrm{j}} / \mathrm{DBH}_{\mathrm{i}}$ respectively.

bLCI_2, 3, 4, 5 and 6 are sum of stepwise additions of 6 nearest neighbours $\mathrm{DBH}_{\mathrm{N}} / \mathrm{DBH}_{\mathrm{CP}}$ by distance from centre pine.

zsch 2009). The shade intolerance of both pine and aspen, together with aspen's dense regeneration and vigorous early growth performance (Frey et al. 2003), suggests that aspen's competitive strength will, over the early stand development period, result in the exclusion of pine. Peterson and Peterson (1995) noted this change towards aspen dominance over pine in Alberta cut blocks and the need to control aspen to improve conifer growth. Brushing treatments will impact the strength and duration of the NN aspen competition but may not necessarily influence long-term aspen presence if stand conditions allow aspen canopy resurgence. Defining the neighbourhood stand dynamics in relation to spatial variability, species composition, NN distance and relative size will provide a basis for quantifying the linkage between brushing efficacy, competition thresholds and plantation performance (Radosevich and Knowe 1992).
Distance independent competition indices (Cl)

The focus on distance-independent CI may be criticized by some since many studies have observed better correlations using distance-dependent competition indices (Mugasha 1989, Linkevicius et al. 2014). However, the interaction of distance within the CI model (Table 2, DRD for example) with the variability of tree spatial distribution was not considered conducive to exploring the relationship between growth and distance (Ledermann and Stage 2001). Free-growing survey assessments (BC MFLNRO 2013) consider proximity to competition and crop tree size somewhat independently, based on survey standards defining "effective growing space" within a 1 $\mathrm{m}$ radius. Therefore, the importance of separating the influence of NN distance on CP relative size (both height and $\mathrm{DBH})$ provides the simplification needed to assess the importance of proximity. The lack of correlation between NN dis- 
Table 6. The predictive ability $\left(\mathrm{R}^{2}{ }_{\text {adj }}\right.$ ) of centre pine growth variables (CPG: $\mathrm{DBH}$ and height, average leader growth for last two years (A_LDR), stem volume (STV) and, relative stem volume (R_STV: CP stem volume / maximum CP stem volume per site)] using the linear model CPG $=a+b$ DIST where the distance to nearest neighbour (DIST) is a sum of nearest neighbours data by site (DIST: stepwise addition of nearest neighbours closest through farthest distance and largest). (Largest $\mathrm{R}^{2}{ }_{\text {adj }}$ bolded). Values presented for significant models only $(P<0.05)$.

\begin{tabular}{|c|c|c|c|c|c|c|c|c|}
\hline Site & CPG & DIST_C ${ }^{a}$ & DIST_2 ${ }^{b}$ & DIST_ $3^{b}$ & DIST_4 ${ }^{b}$ & DIST_5 ${ }^{b}$ & DIST_6 ${ }^{b}$ & DIST_L ${ }^{a}$ \\
\hline \multirow{2}{*}{ Tamarack Lake (BE) } & DBH, HT & - & - & - & - & - & - & - \\
\hline & DR, STV \& R_ & TV - & - & - & - & - & - & - \\
\hline \multirow[t]{4}{*}{ Dog Creek (DG) } & $\mathrm{DBH}$ & 0.35 & 0.41 & 0.44 & 0.45 & 0.45 & 0.45 & 0.48 \\
\hline & HT & 0.22 & 0.40 & 0.43 & 0.41 & 0.38 & 0.34 & 0.29 \\
\hline & A_LDR & - & - & - & - & - & - & - \\
\hline & R_STV, STV & 0.29 & 0.32 & 0.35 & 0.36 & 0.34 & 0.35 & 0.46 \\
\hline \multirow[t]{3}{*}{ Loon Lake (LL) } & $\mathrm{DBH}$ & - & 0.11 & 0.10 & 0.11 & 0.11 & 0.10 & - \\
\hline & HT & - & - & - & - & - & - & - \\
\hline & DR, STV \& R_ & TV - & - & - & - & - & - & - \\
\hline \multirow[t]{4}{*}{ Pitka Creek (PI) } & $\mathrm{DBH}$ & 0.16 & 0.29 & 0.42 & 0.49 & 0.52 & 0.56 & 0.22 \\
\hline & HT & 0.17 & 0.23 & 0.32 & 0.39 & 0.41 & 0.44 & 0.23 \\
\hline & A_LDR & - & - & - & - & - & - & - \\
\hline & R_STV, STV & 0.12 & 0.26 & 0.38 & 0.45 & 0.48 & 0.52 & 0.24 \\
\hline \multirow[t]{4}{*}{ Tako Creek (TC) } & $\mathrm{DBH}$ & 0.20 & 0.20 & 0.19 & 0.21 & 0.24 & 0.26 & 0.12 \\
\hline & $\mathrm{HT}$ & 0.38 & 0.34 & 0.31 & 0.29 & 0.27 & 0.28 & - \\
\hline & A_LDR & 0.13 & 0.14 & 0.13 & 0.13 & 0.14 & 0.16 & 0.17 \\
\hline & R_STV, STV & 0.22 & 0.25 & 0.25 & 0.27 & 0.29 & 0.30 & - \\
\hline \multirow[t]{4}{*}{ Chehishic Creek (CC) } & $\mathrm{DBH}$ & - & 0.11 & 0.24 & 0.32 & 0.36 & 0.36 & 0.11 \\
\hline & $\mathrm{HT}$ & - & - & - & 0.14 & 0.19 & 0.20 & - \\
\hline & A_LDR & - & - & - & - & - & - & - \\
\hline & R_STV, STV & - & - & 0.16 & 0.23 & 0.27 & 0.27 & 0.11 \\
\hline \multirow[t]{4}{*}{ All sites } & $\mathrm{DBH}$ & 0.15 & - & - & - & - & - & - \\
\hline & HT, STV & - & - & - & - & - & - & - \\
\hline & A_LDR & - & - & - & - & - & - & 0.036 \\
\hline & R_STV & 0.073 & 0.11 & - & - & - & - & - \\
\hline
\end{tabular}

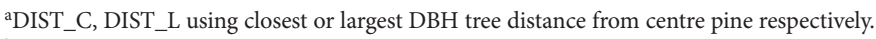

bIST_2, 3, 4, 5, and 6 are sum of stepwise additions of 6 nearest neighbours distance from centre pine.

tance and NN relative size (diameter or height) at the site level (for all NN, not just closest; Fig. 2a \& b) suggested distance (to the $\mathrm{CP}$ ) had no relationship to the relative size of the NN. These results suggest proximity measures are of lesser importance within the context of operational free-growing surveys, in particular the results do not support the continued reliance on a fixed $1.0 \mathrm{~m}$ radius for aspen competition assessment.

The shaded areas of Fig. 3 highlight the importance of considering not only neighbourhood composition but also the relative size of aspen neighbours. The range of the average NN relative height (RHT_A) for the majority of the CP was found to be about 0.8 to 1.2 , irrespective of $\mathrm{NN}$ species composition (see light blue-shaded area) with an average tree height variability $\pm 20 \%$. The green-shaded area indicated the high CP suppression range (RHT_A $=1.2$ to 3.2 ) only occurred where NN aspen composition $\geq 50 \%$ and the severity of the CP suppression increased with aspen dominance.

Linear regression suggested NN relative diameter (LCI) (Table 5 and Fig. 4b) or relative height (RHT) (Fig. 4a) were the most important parameters describing the impact of $\mathrm{NN}$ competition on CP size, and through inference, CP growth. Pooled site results for DBH, leader and R_STV indicated a site independent relationship to NN relative size. Proximity (DIST) results (Table 6, Fig. 4c) showed NN distance was much less important as a descriptor of CP size. The stepwise improvement in the regression results indicated the importance of including additional nearest neighbours (or the largest NN).

\section{Exponential response model}

The exponential model (eq. 1) improved the predictions $\left(\mathrm{R}^{2}{ }_{\text {adj }}\right)$ of the CP relative volume (R_STV) decline with increasing NN LCI_6 competition index, across all sites and NN species (similar results using RHT_6 and RCW_6 were also found but not shown), accounting for $42 \%$ of the variation. Model results suggested superior fits when all NN species were used except for the LL site where superior fit was found with aspen NN (Table 7). Simard et al. (2005) used a similar model to describe lodgepole pine response to increasing broadleaf competition (primarily aspen). The exponential 

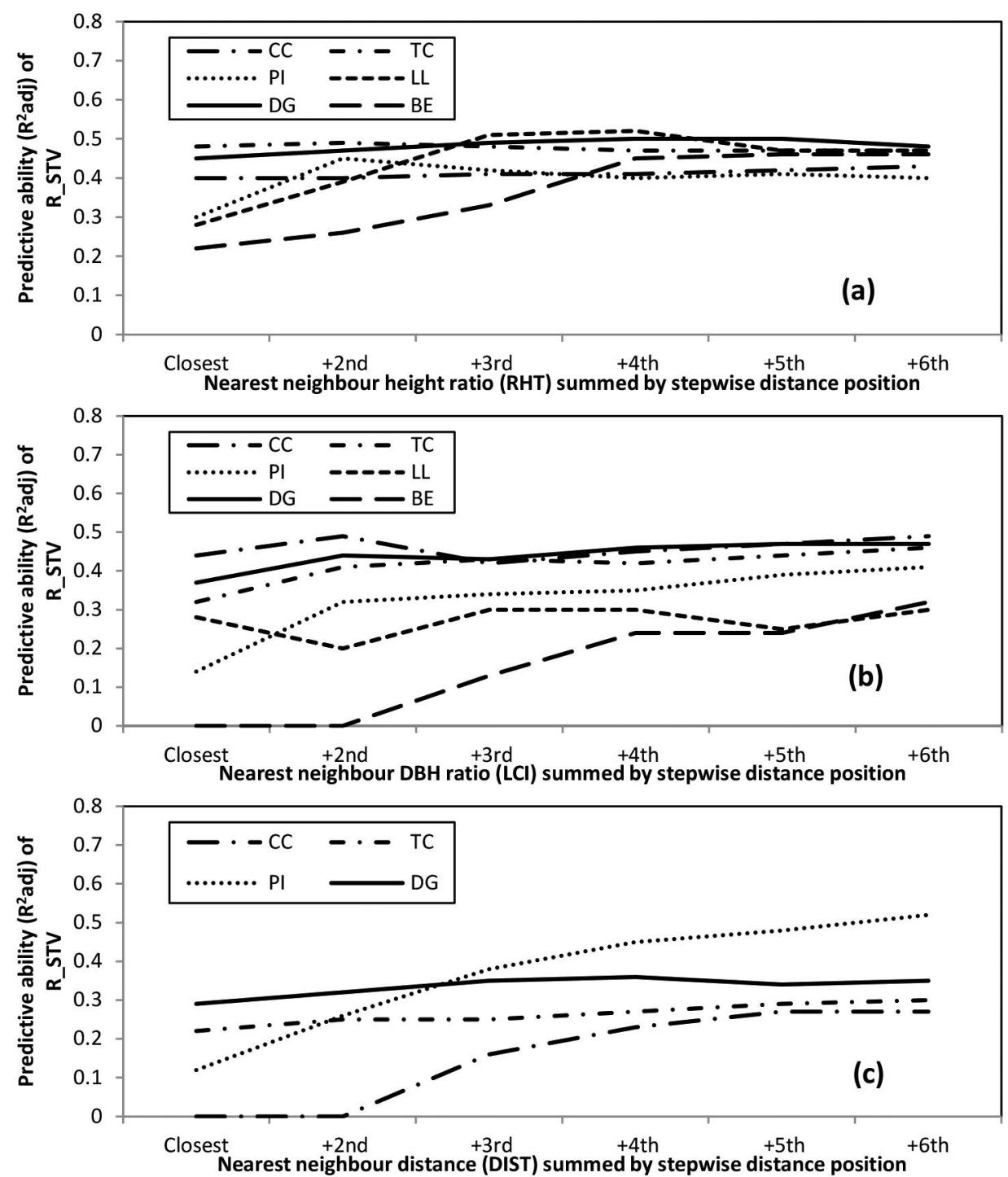

Fig. 4. Lines illustrate the change in predictive ability $\left(R^{2}{ }_{\text {adj }}\right.$ ) by site, of the linear regressions (Proc Reg) describing centre pine relative stem volume (R_STV: CP stem volume / maximum CP stem volume per site) across the stepwise, distance progression of nearest neighbour metrics: a) RHT, b) LCl and c) DIST (see Table 6 \& 7).

declining form of eq. 1 (coefficient b, see Sit and PoulinCostello 1994) highlights the significant CP growth reduction with increasing competition, as defined by $\mathrm{NN}$ relative size (DBH, crown radius or height). Exponential growth equation coefficients were also used by Zeide (1989) to define the rate of decline. Comparison of eq. $1 \mathrm{~b}$ coefficients for the aspen and pine components indicated aspen $\mathrm{NN}$ as having a greater influence on the decline of CP relative growth (larger negative coefficients). Separate model fits using NN aspen and pine components indicated the pine component to be a poor predictor of CP relative growth $\left(\mathrm{R}^{2}\right.$ adj $)$ with the eq. $1 \mathrm{~b}$ coefficients near zero at four of the six sites (BE, DG, PI and CC). This reflects the more linear distribution of the pine $\mathrm{NN}$ data and lack of extreme competition values which are primarily associated with the aspen NN (Fig. 5a \& b).
The all sites eq. 1 model (Table 7) was used to explore a prediction of competition response thresholds using concepts published by Wagner et al. (1989). The calculation of a minimum growth response competition level (such as 20\% of maximum) was considered subjective (Wagner 2000) and found inconclusive, since model results suggested the maximum response threshold was effectively zero. Under this situation the selection of a minimum response threshold requires a measure of stand performance. For example, a $20 \%$ threshold level would require the removal of all NN competitors of relative size (LCI) $>57 \%$ (minimum calculated threshold) effectively eliminating the majority of the intermediate to dominant aspen. Fig. 5a provides a visual reference to the exponential model, presenting the individual NN LCI as the independent variable. The general exponential decline in $\mathrm{CP}$ 
Table 7. Equation coefficients for the fitted exponential model describing each site relationship where R_STV $=a e^{b}$ LCI_6 where R_STV is the CP stem volume/maximum CP stem volume per site and LCI_6 (Lorimer competition index) combines the 6 nearest neighbour (NN) DBHj / DBHi ratios (main model $P$ values $<0.0001$ except for pine at site TC $(P$ value $=0.999$ )

\begin{tabular}{|c|c|c|c|c|c|c|c|c|c|}
\hline \multicolumn{7}{|c|}{ Main model } & \multicolumn{3}{|c|}{ Multiple-site model } \\
\hline $\begin{array}{l}\text { NN } \\
\text { Species }\end{array}$ & Site & $\mathbf{n}$ & $\mathbf{a}$ & $\mathbf{b}$ & $\mathbf{R}_{\text {adj }}^{2}$ & RMSE $^{\mathrm{a}}$ & $\begin{array}{l}\text { Source of } \\
\text { variation }\end{array}$ & $\mathbf{F}$ & $P$ value \\
\hline \multirow[t]{7}{*}{ All } & Tamarack Lake (BE) & 30 & 1.725 & -0.272 & 0.35 & 0.1679 & LCI & 222.55 & $<0.0001$ \\
\hline & Dog Creek (DG) & 30 & 3.06 & -0.331 & 0.63 & 0.1442 & Site & 1.69 & 0.1393 \\
\hline & Loon Lake (LL) & 30 & 1.478 & -0.241 & 0.29 & 0.2163 & LCI $x$ Site & 2.27 & 0.0502 \\
\hline & Pitka Creek (PI) & 30 & 5.481 & -0.43 & 0.56 & 0.2119 & - & - & - \\
\hline & Tako Creek (TC) & 30 & 1.668 & -0.214 & 0.47 & 0.1892 & - & - & - \\
\hline & Chehishic Creek (CC) & 30 & 3.832 & -0.341 & 0.71 & 0.1497 & - & - & - \\
\hline & All sites & 180 & 1.679 & -0.23 & 0.42 & 0.1985 & - & - & - \\
\hline \multirow[t]{6}{*}{ Aspen } & Tamarack Lake & 21 & 0.566 & -0.13 & 0.13 & 0.218 & LCI & 199.65 & $<0.0001$ \\
\hline & Dog Creek & 23 & 0.723 & -0.193 & 0.57 & 0.1559 & Site & 1.47 & 0.2043 \\
\hline & Loon Lake & 23 & 0.725 & -0.226 & 0.38 & 0.1957 & LCI x Site & 3.05 & 0.0127 \\
\hline & Pitka Creek & 22 & 0.745 & -0.178 & 0.46 & 0.186 & - & - & - \\
\hline & Tako Creek & 23 & 0.632 & -0.143 & 0.34 & 0.2114 & - & - & - \\
\hline & Chehishic Creek & 17 & 0.751 & -0.176 & 0.41 & 0.2289 & - & - & - \\
\hline \multirow[t]{6}{*}{ Pine } & Tamarack Lake & 25 & 0.592 & -0.058 & 0.0008 & 0.2064 & LCI & 8.97 & 0.0032 \\
\hline & Dog Creek & 24 & 0.502 & -0.0069 & -0.044 & 0.2207 & Site & 2.36 & 0.043 \\
\hline & Loon Lake & 28 & 0.37 & 0.098 & 0.083 & 0.2388 & LCI x Site & 3.07 & 0.0115 \\
\hline & Pitka Creek & 23 & 0.267 & 0.0201 & 0.28 & 0.2659 & - & - & - \\
\hline & Tako Creek & 27 & - & - & - & - & - & - & - \\
\hline & Chehishic Creek & 27 & 0.593 & -0.0185 & -0.034 & 0.2492 & - & - & - \\
\hline
\end{tabular}

${ }^{\text {a}}$ Root mean squared error.

relative growth (R_STV) with NN LCI is clear, as well as the contribution of not only the aspen $\mathrm{NN}$ in terms of the larger range of competition but also of the contribution of pine NN. This exponential decline in tree size with $\mathrm{NN}$ size is reflective of the general stand dynamics of inter and intraspecific competition between trees. Even within single species stands of pine or aspen we would see this relationship as dominant, intermediate and suppressed individuals influence or impede growth through canopy crowding and below-ground resource competition. Performance expectations will require defined thresholds that quantify impeded pine growth at various levels of aspen competition under various silvicultural options.

\section{Management implications}

Quantifying the impacts associated with increased aspen presence at the stand and tree level is key to understanding long-term pine plantation productivity. This paper together, with Harper (2015), has demonstrated the negative influence of neighbourhood aspen competition on operational post free-growing pine plantation performance. The results do not support aspen thresholds for free-growing assessments since any increase in aspen density and relative size will impact pine tree and stand level performance. Total density by species composition may be useful in predicting post freegrowing stand developments. Present methodology for assessing free growing in BC (BC MFLNRO 2013) suggests up to 1000 tph of aspen (in the SBS) are acceptable within pine plantations. Clearly there is a need to revise the free- growing standards to align with current research evidence and address concerns over the legal definition of a free-growing stand and possible impeded stand growth (BC MFLNRO 2015). Performance- based standards are needed to ensure tree level surveys are linked to long-term stand level performance (Wagner et al. 1989). Silviculture prescriptions and treatments that fail to address aspen competitive strength will lead to varying levels of aspen dominance and therefore varying levels of pine growth reduction. To maintain long-term pine stand productivity, the effectiveness of brushing treatments to reduce or removed aspen dominance must consider the propensity of aspen to regenerate and outgrow planted pine beyond free-growing timelines.

Nearest neighbour relative size measures of diameter and height were found well-correlated with pine growth decline. It is recommended that either of these competition indices be used to assess operational pine performance as part of an overall stand performance assessment that quantifies competition intensity. It is also recommended that the reliance on a fixed-radius area for assessment of aspen competition (in BC it is $1.0 \mathrm{~m}$, BC MFLNRO 2013) be removed as part of a revision of the free- growing guidelines.

\section{Conclusion}

It is imperative that operational foresters do not underestimate the impact of aspen competition on pine performance, stand composition and long-term stand dynamics. Improving stand productivity requires an awareness of inter and intraspecific competition, the tree level processes involved 

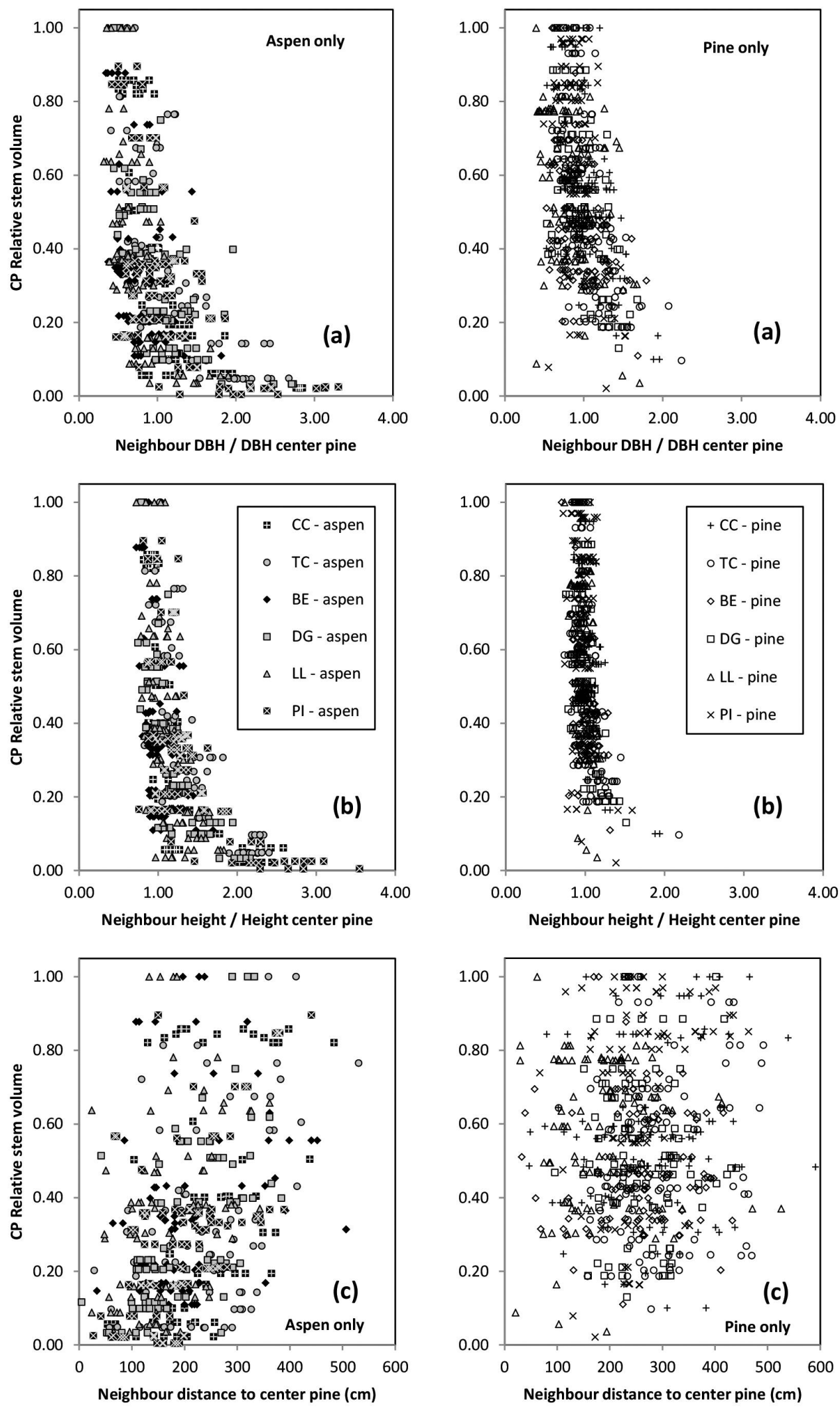

Fig. 5. Centre pine relative stem volume (R_STV, relative to maximum CP STV observed per site) plotted over nearest neighbour competition measures; relative bole size (LCI) (a), relative height (RHT) (b) and distance (DIST) (c). All nearest neighbour data points (1080) are partitioned into separate pine (right column) and aspen (left column) component graphs. 
and the outcomes as they impact performance measures. Foresters need to be aware of the difference between competition intensity and importance (Brooker and Kikvidze 2008). Studies of competition intensity address an understanding of tree level stand dynamics and neighbourhood interactions. Competition importance deals with the quantification of forest values such as yield (Harper 2015), ecology (Royer-Tardif and Bradley 2011), economics and non-timber environmental services (Greiss and Knoke 2011). An understanding of all these values is required if we are to successfully integrate basic silviculture into an effective management regime that optimizes long-term pine plantation performance.

A final comment on the study limitations; in general, retrospective studies should be viewed with caution. The aspen - pine competition gradients examined in this paper were from operational "natural" conditions where no formal treatment manipulations were applied. Assumptions of independence and homogeneity across the sampling regime and competition gradients may have been influenced by unknown underlying environmental factors. The selection of multiple sites did improve confidence in the results, however much more research is needed to improve certainty in the interpretations. Research where competition levels are experimentally controlled is needed to test the results of this study. Monitoring and documentation of the long-term response of pine plantations to aspen and other broadleaf tree competition is essential to ensuring timber supply expectations are on-track and accurate.

\section{Acknowledgements}

This project was funded by the British Columbia Ministry of Forests, Lands and Natural Resource Operations. Technical advice and counsel were provided by Phil Comeau, Cosmin Filipescu, Dave Goldie, Jim Goudie, Catherine Bealle Statland and Louise de Montigny. Statistical advice and review were provided by Peter Ott.

\section{References}

BC MFLNRO. 2013. (B.C. Ministry of Forests, Lands and Natural Resource Operations). Silviculture surveys procedures manual. Available from http://www.for.gov.bc.ca/hfp/silviculture/Surveys/ SilvicultureSurveyProceduresManual-April_1_2013.pdf

BC MFLNRO. 2015. (B.C. Ministry of Forests, Lands and Natural Resource Operations). Forest and Range Practices Act. Victoria, BC. URL: http://www.bclaws.ca/Recon/document/ID/freeside/00_02069_01 Brooker, R.W. and Z. Kikvidze. 2008. Importance: An overlooked concept in plant interaction research. J. Ecol. 96:703-708.

Canham, C.D., P.T. LePage and K.D. Coates. 2004. A neighbourhood analysis of canopy tree competition: Effects of shading versus crowding. Can. J. For. Res. 34: 778-787.

Chen, S. 1997. Interpreting main effects when a two-way interaction is present. B.C. Min. For., Victoria, B.C. Biometrics Information Pamphlet No. 57, 8 p.

Comeau, P.G., B.S. Biring and G.J. Harper. 1999. Conifer response to brushing treatments: A summary of British Columbia data. B.C. Min. For., Res. Br., Victoria, B.C. Exten. Note 41. Available from https://www.for.gov.bc.ca/hfd/pubs/Docs/En/En41.htm

Cornell, J.A. and R.D. Berger. 1987. Factors that influence the value of the coefficient of determination in simple linear and nonlinear regression models. Phytopathology 77: 63-70.

Daniels, R. 1976. Simple competition indices and their correlation with annual loblolly pine tree growth. For. Sci. 22: 454-457.

DeLong, C.S. 2007. Relative impact of aspen competition and soil factors on the performance of lodgepole pine and hybrid white spruce in north-central British Columbia. B.C. Min. For. Range, Res. Br., Victoria, B.C. Tech. Rep. 039.

Demaerschalk, J.P. and A. Kozak. 1974. Suggestions and criteria for more effective regression sampling. Can. J. For. Res. 4: 341-348.

Dhar, A., J.R. Wang and C.D.B. Hawkins. 2015. Interaction of trembling aspen and lodgepole pine in a young sub-boreal mixedwood stand in central British Columbia. Open Journal of Forestry 5: 129-138.

Filipescu, C.N. and P.G. Comeau. 2007. Competitive interactions between aspen and white spruce vary with stand age in boreal mixedwoods. For. Ecol. Manage. 247: 175-184.

Frey, B.R., V.J. Lieffers, S.M. Landhausser, P.G. Comeau, and K.J. Greenway. 2003. An analysis of sucker regeneration of trembling aspen. Can. J. For. Res. 33: 1169-1179.

Greiss, V.C. and T. Knoke. 2011. Growth performance, windthrow, and insects: Meta-analyses of parameters influencing performance of mixed-species stands in boreal and northern temperate biomes. Can. J. For. Res. 41: 1141-1159.

Harper, G. 2015. Lodgepole pine and trembling aspen mixedwoods: Growth and yield within 22 to 39 year-old pine plantations of northern interior British Columbia. Forest. Chron. 91(5): 502-518.

Harper, G.J., M. O’Neill, P. Fielder, T. Newsome and C. Delong. 2009. Lodgepole pine growth as a function of competition and canopy light environment within aspen dominated mixedwoods of central interior British Columbia. For. Ecol. Manag. 257: 1829-1838. Johnstone, W.D. and J.C. Pollack. 1990. The influence of espacement on the growth and development of a lodgepole pine plantation. Can. J. For. Res. 20 (10): 1631-1639.

Johnstone, W.D. and F.J. van Thienen. 2011. The effects of plantation density on the growth and yield of lodgepole pine: 20 year results. B.C. Min. For. Range. For. Sci. Prog., Victoria, B.C. Exten. Note 102. http://www.for.gov.bc.ca/hfd/pubs/Docs/En/En102.htm

Ledermann, T. and A.R. Stage. 2001. Effects of competitor spacing in individual-tree indices of competition. Can. J. For. Res. 31: 2143-2150.

Lhotka, J.M. and E.F. Loewenstein. 2008. An examination of species-specific growing space utilization. Can. J. For. Res. 38: 470-479.

Lieffers, V.J., G.W. Armstrong, K.J. Stadt, and E.H. Marenholtz. 2008. Forest regeneration standards: Are they limiting management options for Alberta's boreal mixedwoods? Forest. Chron. 84:76-82. Linkevicius, E., A. Kuliesis, H. Rohle, J. Schroder and M. Aleinikovas. 2014. The impact of competition for growing space on diameter, basal area and height growth in pine trees. Baltic Forestry 20 (2): 301-312.

Lorimer, C.G. 1983. Tests of age-dependent competition indices for individual trees in natural hardwood stands. For. Ecol. Manage. 6: 343-360.

McKinnon, L.M. and G.J. Kayahara. 2003. Ecology and management of microclimate in boreal mixedwoods. Northeast Science and Information, Ont. Min. Natural Resour., South Porcupine, Ont. Boreal Mixedwood Notes 28. 13 p.

Meidinger, D. and J. Pojar. 1991. Ecosystems of British Columbia. B.C. Min. For., Res. Br., Victoria, B.C. Spec. Rep. Ser. 6. Available from https://www.for.gov.bc.ca/hfd/pubs/docs/srs/Srs06.pdf

Miller, J.H., Zutter, B.R., Zedaker, S.M., Edwards, M.B., Newbold, R.A. 2003. Growth and yield relative to competition for loblolly pine plantations to midrotation- A southern United States regional study. South J. Appl. For. 27(4): 237-252.

Miller, J.H., Zutter, B.R., Zedaker, S.M., Edwards, M.B., Haywood, J.D. and R.A. Newbold. 1991. A regional study on the influence of woody and herbaceous competition on early loblolly pine growth. South. J. Appl. For. 15: 169-179.

Mugasha, A.G. 1989. Evaluation of simple competition indices for the prediction of volume increment of young jack pine and trembling aspen trees. For. Ecol. Manage. 26: 227-235. 
Neter, J., W. Wasserman, and M.H. Kutner. 1990. Applied linear statistical models: Regression, analysis of variance, and experimental designs. $3^{\text {rd }}$ ed. Irwin, Inc.

Newsome, T. 1999. Assessing the effects of aspen competition on lodgepole pine growth in the IDFdk 3\&4. Extension Note \#27. Research Section, Ministry of Forests, Cariboo Forest Region, Williams Lake, B.C.

Newsome, T.A., J.L. Heineman and A.F.L. Nemec. 2003. Competitive effects of trembling aspen on lodgepole pine performance in the SBS and IDF zones of the Cariboo-Chilcotin region of southcentral British Columbia. B.C. Min. For., Res. Br., Victoria, B.C. Tech. Rep. 005.

Newsome, T.A., J.L. Heineman and A.F.L. Nemec. 2008. Competitive interactions between juvenile trembling aspen and lodgepole pine: A comparison of two interior British Columbia ecosystems. For. Ecol. Manag. 255: 2950-2962.

Peterson, E.B. and N.M. Peterson. 1995. Aspen manager's handbook for British Columbia. FRDA Report No. 230. B.C. Ministry of Forests, Victoria, B.C. 110 p. Available from https://www.for.gov. bc.ca/hfd/pubs/docs/Frr/Frr230.pdf

Pretzsch, H. 2009. Forest dynamics, growth and yield: From measurements to model. Chapter 9, pp. 337-380. Springer-Verlag Berlin Heidelberg. 664 pp. Available from http://www.crc.uqam.ca/Publication/Forest\%20Dynamics,\%20Growth\%20and\%20Yield.pdf

Pretzsch, H. and P. Biber. 2016. Tree species mixing can increase maximum stand density. Can. J. For. Res. 46: 1179-1193.

Radosevich S.R. and S.A. Knowe. 1992. Approaches and interpretation of experiments in forest vegetation management. Paper presented at the International Conference on Forest Vegetation Management, Auburn, U.S.A., 26 April-1 May.

Royer-Tardif, S. and R.L. Bradley. 2011. Evidence that soil fertility controls the mixing of jack pine with trembling aspen. For. Ecol. Manage. 262: 1054-1060.

SAS Institute Inc. 2010. SAS OnlineDoc ${ }^{\circledR}$ 9.3., Cary, NC: SAS Institute Inc.
Simard, S.W., S.M. Hagerman, D.L. Sachs, J.L. Heineman and W.J. Mather. 2005. Conifer growth, Armillaria ostoyae root disease, and plant diversity responses to broadleaf competition reduction in mixed forests of southern interior British Columbia. Can. J. For. Res. 35: 843-859.

Sit, V. and M. Poulin-Costello. 1994. Catalog of curves for curve fitting. Biometrics information handbook series. Handbook No. 4. March 1994. Res. Br., B.C. Min. For., Victoria, B.C. Available from http://www.for.gov.bc.ca/hfd/pubs/Docs/Bio/Bio04.htm

South, D.B. and J.H. Miller. 2007. Growth response analysis after early control of woody competition for 14 loblolly pine plantations in the southern U.S. For. Ecol. Manage. 242: 569-577.

Voicu, M.F. and P.G. Comeau. 2006. Microclimate and spruce growth gradients adjacent to young aspen stands. For. Ecol. Manage. 221: 13-26.

Wagner, R.G., 2000. Competition and critical-period thresholds for vegetation management decisions in young conifer stands. Forest. Chron. 76: 961-968.

Wagner, R.G., T.D. Petersen, D.W. Ross and S.R. Radosevich. 1989. Competition thresholds for the survival and growth of ponderosa pine seedlings associated with woody and herbaceous vegetation. New Forests 3: 151-170.

Wagner, R.G., K.M. Little, B. Richardson and K. McNabb. 2006. The role of vegetation management for enhancing productivity of the world's forests. Forestry 79 (1): 57-79.

Walmsley, M., G. Utzig, T. Vold, D. Moon and J. van Barneveld. 1980. Describing ecosystems in the field. RAB technical paper 2. Land Management Report No. 7. Province of B.C., Victoria, B.C. Available from http://www.llbc.leg.bc.ca/public/PubDocs/bcdocs/ 264741/Lmr007.pdf

Zeide, B. 1989. Accuracy of equations describing diameter growth. Can. J. For. Res. 19: 1283-1286.

Zeide, B. 2002. Analysis of a concept: Stand density. J. Sustain. Forest. 14 (4): 51-62. 